\title{
A NEW SPECIES OF ILYOPLAX (DECAPODA, BRACHYURA, DOTILLIDAE) FROM PANGLAO, THE PHILIPPINES
}

\author{
BY \\ PETER J. F. DAVIE ${ }^{1,3}$ ) and TOHRU NARUSE ${ }^{2,4}$ ) \\ 1) Queensland Museum, P.O. Box 3300, South Brisbane, Queensland, 4101, Australia \\ ${ }^{2}$ ) Transdisciplinary Research Organization for Subtropical and Island Studies, University of \\ the Ryukyus, 870 Uehara, Taketomi, Okinawa 907-1541, Japan
}

\begin{abstract}
A new species of Ilyoplax, I. danielae, is described from the Philippines. It differs from its closest congeners, I. stapletoni (De Man, 1908), I. ningpoensis Shen, 1940, and I. formosensis Rathbun, 1921, by differences in carapace shape and proportions, shape and dentition of the chela and the morphologies of the walking legs and male first gonopods.

\section{RÉSUMÉ}

Une nouvelle espèce d'Ilyoplax, I. danielae est décrite des Philippines. Elle diffère de ses congénères les plus proches, I. stapletoni (De Man, 1908), I. ningpoensis Shen, 1940, et I. formosensis Rathbun, 1921, par des différences portant sur la forme et les proportions de la carapace, la forme et les dents de la pince et la morphologie des pattes marcheuses et des gonopodes mâle.
\end{abstract}

\section{INTRODUCTION}

The genus Ilyoplax Stimpson, 1848, has had relatively little taxonomic attention since the 1930s, with only two new species having been described in recent times: I. strigicarpus Davie, 1990, from northern Australia, and I. pacifica Kitaura \& Wada, 2006, from the Philippines and Indonesia. Both species are closely allied to I. orientalis (De Man, 1888). There are currently

\footnotetext{
3 ) Corresponding author; e-mail: Peter.Davie@qm.qld.gov.au

$\left.{ }^{4}\right)$ e-mail: naruse@lab.u-ryukyu.ac.jp 
26 species recognized (see $\mathrm{Ng}$ et al., 2008), but an ongoing revision of this group by Davie \& Kosuge indicates not only a number of new species, but also that Ilyoplax is polyphyletic and as such it will need to be split into several new genera. This concurs with recent behavioural and DNA phylogenetic studies by Kitaura \& Wada $(1998,2006 b)$ that also recognized three separate lineages within Ilyoplax. An earlier review of the genus by Serène \& Lundoer (1974) also recognized three primary groups based on the morphology of the male first gonopod, although I. integer (Tesch, 1918) was considered to stand alone. In addition, their "Group II" was also found not to be homogeneous. Serène \& Lundoer (1974) provided the most recent published key to Ilyoplax sensu lato.

Ilyoplax species, though typically small in size, can numerically dominate the shores on which they occur, and thus have some ecological significance (see Snowden et al., 1991). Like other shore Ocypodoidea they also have evolved some complex and noteworthy behaviours, and these have been the subject of numerous studies (e.g., Wada, 1981, 1983a-c, 1984, 1987a, b; Kosuge et al., 1994; Kitaura \& Wada, 1998, 2006a).

The new species reported here was collected as part of the PANGLAO Marine Biodiversity Project of 2004 undertaken by the Raffles Museum of Biodiversity Research, Singapore, the Museum national d'Histoire naturelle, Paris, and the Philippine National Museum, Manila. Extensive collections were made from Panglao Island area in Bohol, the Philippines, by sampling of mudflats, seagrass beds and mangroves, and by scuba diving, trawling, dredging, trapping, and tangle netting. Together with collections from the PANGLAO Deep-Sea Cruise in 2005, it has been estimated that between 150 and 250 new crustacean species have been discovered from a total of more than 1200 identified decapods (see Bouchet et al., 2009).

The material examined is deposited in the Crustacean Collection of the National Museum of the Philippines (NMCR), Manila; Zoological Reference Collection (ZRC) of the Raffles Museum of Biodiversity Research, National University of Singapore; and the Queensland Museum (QM), Brisbane. The abbreviations P2-P5 refer to the pereopods 2-5, respectively; and G1 refers to the male first gonopod. Measurements provided are of the carapace width $(\mathrm{CW})$ and length (CL), respectively. 


\section{TAXONOMY}

DotILLIDAE Stimpson, 1858

Ilyoplax Stimpson, 1858

Ilyoplax Stimpson, 1858: 98. (Type species: Ilyoplax tenella Stimpson, 1858 by monotypy.)

Dioxippe De Man, 1888: 137 (junior homonym of Dioxippe Thomson, 1860 [Insecta, Coleoptera]; gender feminine). (Type species: Dioxippe orientalis De Man, 1888 by subsequent designation of Davie, 2002.)

Tympanomerus Rathbun, 1897: 164 (new name for Dioxippe De Man, 1888; gender masculine).

\section{Ilyoplax danielae sp. nov. (figs. 1, 2)}

Material examined. - Holotype: NMCR, male $(5.4 \times 3.9 \mathrm{~mm})$, Stn B31, Dauis, Panglao I., Bohol Province, Philippines, rubble on sandy bottom and seagrass, $1-2 \mathrm{~m}, 9^{\circ} 38.7^{\prime} \mathrm{N}$ $123^{\circ} 50.4^{\prime} \mathrm{E}$, coll. PANGLAO 2004 Expedition, 26 June 2004. Paratypes: QM-W28924, male $(4.6 \times 3.3 \mathrm{~mm})$, data as for holotype. ZRC, female $(5.2 \times 3.7 \mathrm{~mm})$, Stn M47, Panglao, Philippines, fringe of mangrove, 0-0.5 m, middle part of Danao embayment, $9^{\circ} 33.6^{\prime} \mathrm{N} 123^{\circ} 45.1^{\prime} \mathrm{E}$, coll. PANGLAO 2004 Expedition, 29 June 2004.

Etymology. - Named in honour of our friend and mentor Danièle Guinot. The species epithet is used as a noun in the genitive case.

Description. - Carapace (figs. 1, 2A) sub-rectangular, 1.4 times as wide as long, widest between anterolateral angles, lateral margins slightly converging posteriorly; regions poorly defined; smooth or microscopically granular, with short transverse ridges edged with very short setae. Front relatively broad, about one-quarter distance between exorbital angles, noticeably deflexed, lateral borders converging, rounded; distinctly concave dorsally. Gastrocardiac groove defined; cardiac region with low swelling on either side of mid-line, each bearing transverse ridge; branchial regions with several low oblique setiferous crests posterolaterally. Posterior border straight, broadly rounded laterally, with broad rim. Supraorbital borders moderately sinuous; sloping obliquely backward; smooth. Exorbital angles bluntly rounded, separated from rounded anterolateral prominence by broad shallow sulcus; anterolateral margin minutely granular, extending as oblique ridge for short distance onto dorsal carapace surface. Infraorbital borders project beyond supraorbital borders medially; evenly granular; slightly sinuous, separated from exorbital angle by V-shaped notch; secondary minutely granular ridge extending below ocular peduncle from adjacent to basal antennal segment, creating a broad, transverse sulcus in front of orbit. Eyestalks thick, approx. 0.4 times distance between exorbital angles; cornea bulbous. 


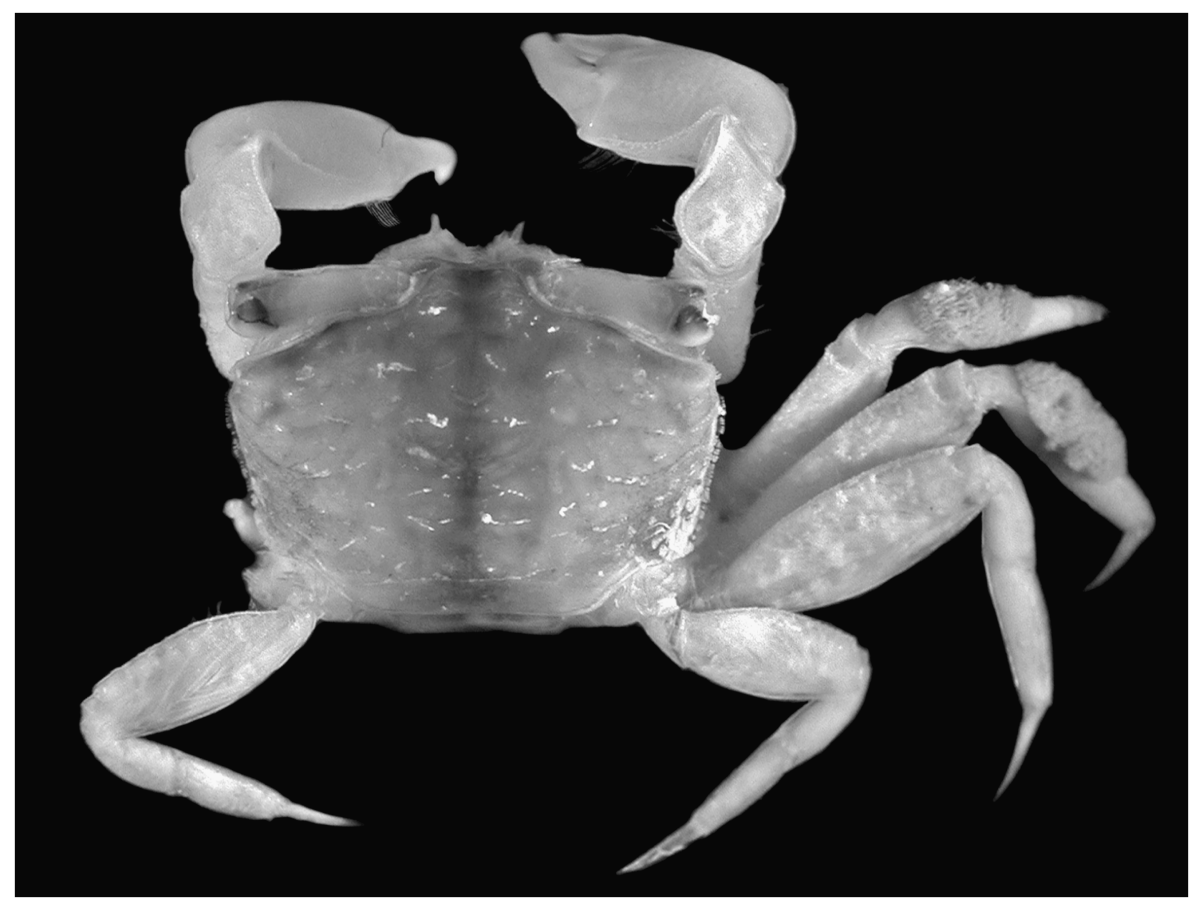

Fig. 1. Ilyoplax danielae sp. nov., holotype male $(5.4 \times 3.9 \mathrm{~mm})$, Panglao I., Bohol Province, Philippines (NMCR).

Third maxillipeds (fig. 2B) with merus longer than ischium (approx. 1.3 $\times$ ); antero-internal angle of ischium broadly triangular; produced along edge of merus; ischium with oblique distolateral line of microscopic granules equipped with long plumose setae, longest near outer margin. Maxillipeds moderately bulging; completely closing buccal cavity.

Male abdomen (fig. 2G) with telson elongate, apically rounded, slightly shorter and narrower than sixth somite; sixth somite with sub-parallel margins, 1.15 times as long as wide; fifth somite much shorter (approx. $0.66 \times$ ) than sixth, markedly constricted at about 0.4 height from base; fourth and third somites similar, fourth slightly narrower, with slightly concave lateral margins; second short, similar in width; first with transverse keel subparallel to anterior margin. Female abdomen relatively narrow (fig. 2F).

Chelipeds (fig. 2C) massive, equal; merus trihedral, inner and outer margins granular, posterior border rounded; outer face sparsely granular; inner face with vertical medial band of small, well-spaced granules. Carpus short, rhomboidal, unarmed. Chela of adult male holotype greatly inflated, with broad gape basally between fingers; dorsal margin of palm marked by raised granular 


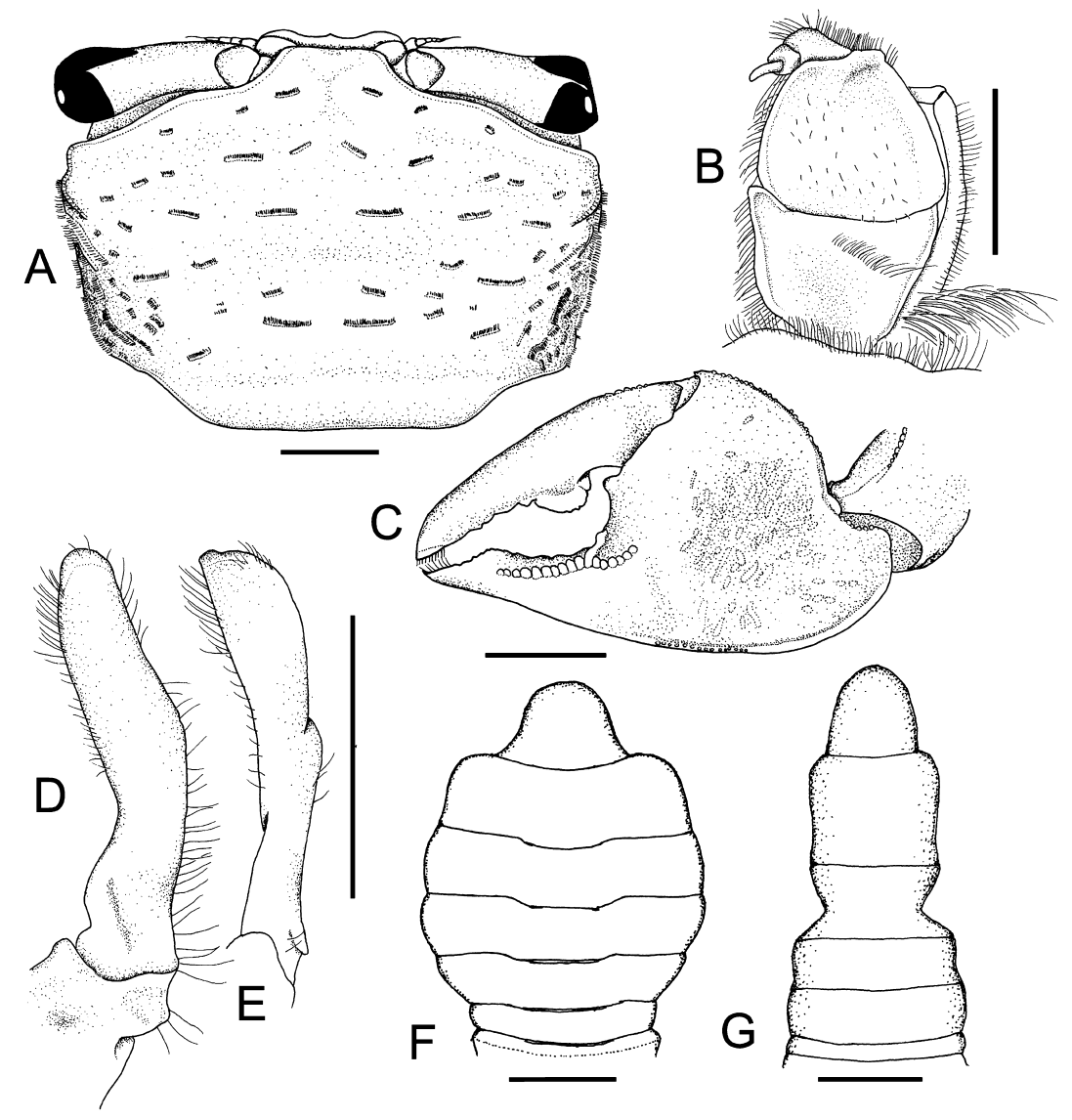

Fig. 2. Ilyoplax danielae sp. nov., A-E, G, holotype male, Panglao I., Bohol Province, Philippines (NMCR); F, paratype female (ZRC). A, carapace; B, third maxilliped; C, left chela external aspect; D, G1 abdominal view; E, G1 sternal view; F, female abdomen; G, male abdomen. Scale lines $=1 \mathrm{~mm}$.

rim extending from articulation with carpus to inner edge of dactylus; outside face smooth; lower margin with finely granular low crest extending full length almost to tip of fixed finger. Fixed finger with cutting margin with low teeth becoming granular distally; slightly raised broad subdistal tooth; accessory row of large granules arising subdistally outside cutting margin, extending to base of finger, terminating in short, upwardly directed arc of larger granules. Fingers hollowed, tipped with chitinous rim, brush of setae on inner tips. Upper margin of dactyl finely granular; cutting margin with low teeth over distal half; large, broad, rounded tooth differentiated in basal half.

P2-P4 all of similar length; relatively broad; P4 merus approx. 2.3 times as long as wide, about same length as carpus and propodus combined; dactylus 
slender, smooth, tapering to acute point, noticeably shorter than propodus. Tympani not present on either face of meri. Dense fur present on distal twothirds of carpus and proximal half of propodus of $\mathrm{P} 2$ and $\mathrm{P} 3$.

G1 (fig. 2D, E) short, thick, not tapering distally; slightly twisted medially; apex bluntly rounded, without obvious prominences, lobes or thick spines.

Habitat. - The species was collected from the edge of mangroves and seagrass beds in the intertidal zone.

Geographical distribution. - Only known from Panglao Island, Bohol Sea, central Philippines.

Remarks. - Using the key of Serène \& Lundoer (1974), the present specimens of Ilyoplax danielae sp. nov. arrive at the last couplet that includes I. stapletoni (De Man, 1908) and I. ningpoensis Shen, 1940. Neither of these species are very similar. The carapace of I. stapletoni has more convex lateral margins and is widest medially, whereas in I. danielae the lateral margins are moderately convergent posteriorly, and the widest point is between the anterolateral angles just posterior to the orbit. The walking legs of I. stapletoni are also relatively more slender and lack the fur of setae on the P2-P4 carpi and propodi, and the male chela also lacks the large differentiated tooth near the base of the cutting margin of the dactylus.

Ilyoplax ningpoensis is a much larger species (adults to approximately $10 \mathrm{~mm} \mathrm{CW}$ ); the carapace is proportionately wider (approx. 1.5 times as wide as long) than I. danielae (1.4 times); the meri of the walking legs are relatively broader, with those of $\mathrm{P} 2-\mathrm{P} 4$ possessing tympani; and the male G1 is of a different form, possessing a long, tongue-like apical extension.

Ilyoplax danielae is most similar in carapace shape to I. formosensis Rathbun, 1921. It is also similar to the latter in lacking stridulatory teeth on the lower orbital margin, having short, broad legs with a thick fur of setae on the carpus and propodus of $\mathrm{P} 2$ to $\mathrm{P} 4$, and similar chela dentition. Ilyoplax formosensis, however, has a tympanum on the meri of the walking legs, lacks a marked constriction at the fifth segment of the male abdomen, and has an obviously different male G1 shape (cf. Serène \& Lundoer, 1974, fig. 9).

Another species of Ilyoplax, I. philippinensis (Rathbun, 1914) was described from the shore at Guihulngan, Negros Island, in the central Philippines, relatively close to the north-west of Panglao Island. This species is still poorly known, but is being redescribed as part of the revision of the genus (P. J. F. Davie \& T. Kosuge, work in progress). Ilyoplax philippinensis differs in the shapes of the carapace and gonopods and, most importantly, it lacks the strongly constricted fifth segment of the male abdomen that is characteristic of a large group of Ilyoplax species including I. danielae sp. nov. 


\section{ACKNOWLEDGEMENTS}

We would like to thank Peter K. L. Ng of the National University of Singapore for passing the material to us and for encouraging us to describe this new species. The PANGLAO 2004 Expedition was organized by MNHN (Philippine Bouchet) together with the National University of Singapore (NUS, P. K. L. Ng), University of San Carlos (Danilo Largo) and National Museum of the Philippines (Marivene Manuel), with the financial support of TOTAL Foundation, ASEAN Regional Centre for Biological Conservation, MNHN and NUS; and we thank them all for their help. The first author is also grateful for the support of the Australian Biological Resources Study (Grant nos. 207-50 and 208-72); and a research fellowship to ZRC from NUS. The second author was also supported by a post-doctoral fellowship to NUS.

\section{REFERENCES}

Bouchet, P., P. K. L. NG, D. LARGo \& S. H. TAN, 2009. PANGLAO 2004. Investigations of the marine species richness in the Philippines. Raffles Bulletin of Zoology, Supplement No. 20: 1-19.

DAVIE, P. J. F., 1990. New and rare crabs of the subfamily Dotillinae (Crustacea: Ocypodidae) from northern Australia and New Guinea. Memoirs of the Queensland Museum, 28 (2): 463-473.

— _, 2002. Crustacea: Malacostraca: Eucarida (Part 2: Anomura, Brachyura): 1-630. (CSIRO Publishing, Melbourne).

KitAurA, J. \& K. WADA, 2006a. Evolution of waving display in brachyuran crabs of the genus Ilyoplax. Journal of Crustacean Biology, 26 (4): 455-462.

- $-\& \_-, 2006 \mathrm{~b}$. New species of Ilyoplax (Brachyura: Ocypodidae: Dotillinae) from the Philippines and Indonesia: behavioural, molecular, and morphological evidence. Raffles Bulletin of Zoology, 54 (2): 373-379.

KitAuRA, J., K. WADA \& M. NishidA, 1998. Molecular phylogeny and evolution of unique mud-using territorial behavior in ocypodid crabs (Crustacea: Brachyura: Ocypodidae). Molecular Biology and Evolution, 15 (6): 626-637.

Kosuge, T., S. Poovachiranon \& M. Murai, 1994. Male courtship cycles in three species of tropical Ilyoplax crabs (Decapoda, Brachyura, Ocypodidae). Hydrobiologia, 285: 93100.

MAN, J. G. DE, 1888. Report on the podophthalmous Crustacea of the Mergui Archipelago, collected for the Trustees of the Indian Museum, Calcutta, by Dr John Anderson, F.R.S., Superintendent of the Museum. Part III. Journal of the Linnean Society of London, 22 (138): 129-176, pls. 9-12.

— - 1908. Decapod Crustacea, with an account of a small collection from Brackish water near Calcutta and in the Decca District, eastern Bengal. In: The fauna of brackish ponds at Port Canning, Lower Bengal, Part X. Records of the Indian Museum, Calcutta, 2: 211-231, 2 pls. 
NG, P. K. L., D. Guinot \& P. J. F. DaVie, 2008. Systema Brachyurorum: Part I. An annotated checklist of extant brachyuran crabs of the world. Raffles Bulletin of Zoology, (Supplement) 17: 1-286.

Rathbun, M. J., 1897. A revision of the nomenclature of the Brachyura. Proceedings of the Biological Society of Washington, 11: 153-167.

- - , 1914. New species of crabs of the families Grapsidae and Ocypodidae. Scientific Results of the Philippine Cruise of the Fisheries Steamer "Albatross", 1907-1910, 31. Proceedings of the United States National Museum, 47 (2044): 69-85.

— - 1921. New species of crabs from Formosa. Proceedings of the Biological Society of Washington, 34: 155-156.

SERÈNE, R. \& S. LUNDOER, 1974. Observations on the male pleopod of the species of Ilyoplax Stimpson with a key to the identification of the species. Phuket Marine Biological Center Research Bulletin, 3: 1-10, figs. 1-11.

SHEN, C. J., 1940. On the collections of crabs of South China. Bulletin of the Fan Memorial Institute of Biology, Peiping, 10 (2): 69-104.

Snowden, R. J., D. A. Clayton \& E. Y. Al-TAher, 1991. Population biology of Ilyoplax stevensi (Brachyura: Ocypodidae) on a Kuwait mudflat. Marine Ecology Progress Series, 71: $219-225$.

STIMPSON, W., 1858. Prodromus descriptionis animalium evertebratorum, quae in Expeditione ad Oceanum Pacificum Septentrionalem, a Republica Federata missa, Cadwaladaro Ringgold et Johanne Rodgers Ducibus, observavit et descripsit W. Stimpson. Pars. V. Crustacea Ocypodoidea. Proceedings of the Academy of Natural Sciences of Philadelphia, 10: $93-110$.

Tesch, J. J., 1918. The Decapoda Brachyura of the Siboga-Expedition. I. Hymenosomidae, Retroplumidae, Ocypodidae, Grapsidae, and Gecarcinidae. Siboga-Expeditie Monographie, 39c: 1-148, pls. 1-6.

WADA, K., 1981. Growth, breeding, and recruitment in Scopimera globosa and Ilyoplax pusillus (Crustacea: Ocypodidae) in the estuary of Waka River, middle Japan. Publications of the Seto Marine Biological Laboratory, 26: 243-259.

_ _, 1983a. Movement of burrow location in Scopimera globosa and Ilyoplax pusillus (Decapoda: Ocypodidae). Physiology and Ecology Japan, 20: 1-21.

—, $1983 \mathrm{~b}$. Spatial distributions and population structures in Scopimera globosa and Ilyoplax pusillus (Decapoda: Ocypodidae). Publications of the Seto Marine Biological Laboratory, 27: 281-291.

— - 1983c. Temporal changes of spatial distributions of Scopimera globosa and Ilyoplax pusillus (Decapoda: Ocypodidae) at co-occurring areas. Japanese Journal of Ecology, 33: $1-9$.

— —, 1984. Barricade building in Ilyoplax pusillus (De Haan) (Crustacea: Brachyura). Journal of Experimental Marine Biology and Ecology, 83: 73-88.

— - 1987a. Neighbor burrow-plugging in Ilyoplax pusillus (Crustacea: Brachyura, Ocypodidae). Marine Biology, Berlin, 95: 299-303.

—, $1987 \mathrm{~b}$. Use of barricades as foraging sites by Ilyoplax pusillus (Crustacea: Brachyura: Ocypodidae). Journal of Ethology, 5: 161-164.

WADA, K. \& C.-H. WANG, 1998. Territorial and sexual behaviours in Ilyoplax formosensis and I. tansuiensis (Crustacea, Brachyura, Ocypodidae). Journal of Taiwan Museum, 51: 119-125.

First received 20 July 2009.

Final version accepted 30 July 2009. 